\title{
DESKRIPSI PENGELOLAAN PENDIDIKAN KARAKTER DI SEKOLAH MENENGAH PERTAMA AL MUSLIM TAMBUN
}

\section{Isep Djuanda}

STAI Al Hamidiyah Jakarta

Email: isep_dj@yahoo.com

\begin{abstract}
This study is aimed to figure out character education management in SMP $\mathrm{Al}$ Muslim Tambun and to uncover the obstacles in managing character education in SMP Al Muslim.

The research design used is qualitative research design which describes the management of character education. The data collection technique employed are observation, interview, and documentary study. Data analytical technique used in this research are qualitative descriptive which will be applied as the approach to describe the result of observation, interview and documentary study.

The research results show us that 1) character education management in SMP Al Muslim Tambun is conducted through school management, learning activities, as well as habitual/coaching activities; 2) the obstacles in managing character education in SMP Al Muslim Tambun are caused by internal and external factors. Internal factors include students and teachers/employees. Meanwhile, the external factors come from parents, shuttle service and foundation.
\end{abstract}

Key words: Management, Character, Character Education 


\begin{abstract}
ABSTRAK
Penelitian ini bertujuan untuk nengetahui pengelolaan pendidikan karakter di SMP Al Muslim Tambun dan mengetahui hambatan dalam pengelolaan pendidikan karakter di SMP Al Muslim

Desain penelitian yang digunakan adalah desain penelitian kualitatif yang mendiskripsikan pengelolaan pendidikan karakter. Teknik pengumpulan data yang digunakan adalah observasi, wawancara, dan studi dokumentasi. Teknik analisis data dalam penelitian ini menggunakan analisis data deskriptif kualitatif yang akan di-jadikan pendekatan untuk menggambarkan hasil dari observasi, wawancara, dan studi dokumentasi.

Hasil penelitian menunjukkan: 1) Pengelolaan pendidikan karakter di SMP Al Muslim Tambun dilaksanakan melalui pengelolaan sekolah, melalui kegiatan pembelajaran dan melalui kegiatan pembiasaan/pembinaan; 2) Hambatan dalam pengelolaan pendidikan karakter di SMP Al Muslim Tambun disebabkan oleh faktor internal dan faktor eksternal. Faktor internal terdiri diri peserta didik dan guru/-karyawan. Sedangkan faktor eksternal terdiri dari orangtua peserta didik, antar jemput peserta didik dan Yayasan.
\end{abstract}

Kata kunci : Pengelolaan, Karakter, Pendidikan Karakter.

\title{
Pendahuluan
}

\section{Latar Belakang Masalah}

Kemajuan peradaban suatu bangsa menunjukan kemajuan peradaban manusianya. Semakin tinggi sebuah peradaban, mengindikasikan semakin maju manusianya. Oleh karenanya, membangun karakter bangsa selalu menjadi jalan untuk membangun sebuah peradaban.

Semangat untuk menjadi bangsa yang berkarakter ditegaskan oleh Proklamator Soekarno dengan mencanangkan nation and character building dalam rangka membangun dan mengembangkan karakter bangsa Indonesia guna mewujudkan cita-cita bangsa, yaitu masyarakat yang adil dan makmur berdasarkan Pancasila. Eksistensi suatu bangsa sangat ditentukan oleh karakter yang dimilikinya. Hanya bangsa yang memiliki karakter kuat yang mampu menjadikan dirinya sebagai bangsa yang bermartabat dan disegani oleh bangsa - bangsa lain. Oleh karena itu, menjadi bangsa yang berkarakter adalah keinginan kita semua.

Upaya pembentukan karakter sesuai dengan budaya bangsa ini tentu tidak semata-mata hanya dilakukan di sekolah melalui serangkaian kegiatan belajar mengajar dan di luar sekolah, akan tetapi juga melalui pembiasaan dalam kehidupan, seperti: berperilaku religius, jujur, disiplin, toleran, kerja keras, cinta damai, tanggung-jawab, dan sebagainya. Pembiasaan itu bukan hanya mengajarkan pengetahuan tentang hal-hal yang benar dan salah, akan tetapi juga mampu merasakan terhadap nilai yang baik dan tidak baik, serta bersedia melakukannya dari lingkup terkecil seperti keluarga sampai dengan cakupan yang lebih luas di masyarakat. Nilai-nilai tersebut perlu ditumbuh kembangkan kepada peserta didik yang pada akhirnya akan menjadi cerminan hidup berbangsa dan bernegara.

Pendidikan karakter bukan hanya sekedar mengajarkan mana yang benar dan mana yang salah. Lebih dari itu, pendidikan karakter adalah usaha menanamkan kebiasaan-kebiasaan yang baik (habituation) sehingga peserta didik mampu bersikap dan bertindak berdasarkan nilai-nilai yang telah menjadi kepribadiannya. Dengan kata lain, pendidikan karakter yang baik 
harus melibatkan pengetahuan yang baik (moral knowing), perasaan yang baik atau loving good (moral feeling) dan perilaku yang baik (moral action) sehingga terbentuk perwujudan kesatuan perilaku dan sikap hidup peserta didik. ${ }^{1}$

Sekolah memiliki peran besar dalam pengembangan pendidikan karakter, karena peran sekolah sebagai pusat pembudayaan melalui pendekatan pengembangan budaya sekolah (school culture). Melalui pendidikan diharapkan dapat menumbuh kembangkan karakter positif, serta mengubah watak dari yang tidak baik menjadi baik.

Sekolah Menengah Pertama (SMP) adalah jenjang pendidikan dasar pada pendidikan formal di Indonesia setelah lulus dari Sekolah Dasar (SD atau sederajat). Sekolah menengah pertama ditempuh dalam kurun waktu 3 tahun (kelas 7 sampai kelas 9). Dari sisi usia, anak SMP adalah anak usia 13-15 tahun (usia remaja)

Usia remaja merupakan masa transisi dari masa anak-anak menuju masa dewasa pertama, dimana bimbingan dan arahan dari sekolah dan keluarga diperlukan dalam menyikapi berbagai persoalan dirinya dan menyikapi realitas yang terjadi di masyarakat dimana masalah kenakalan remaja, pergaulan bebas, merokok, kekerasan masih menjadi persoalan yang mengkhawatirkan.

Dalam konteks ini, penguatan pendidikan karakter menjadi hal yang penting dan utama dalam membangun karakter bangsa. Penelitian ini berupaya untuk mendeskripsikan pengelolaan pendidikan karakter di SMP Al Muslim Tambun.

\section{Tujuan Penelitian}

Penelitian ini dilaksanakan dengan tujuan:

a. Mengetahui pengelolaan program pendidikan karakter di SMP Al Muslim Tambun.

b. Mengetahui hambatan pengelolaan pendidikan karakter di SMP Al Muslim Tambun.

\section{Tinjauan Teori}

1. Hakekat Pendidikan Karakter

a. Pengertian karakter.

Menurut Pusat Bahasa Depdiknas karakter diartikan sebagai "bawaan, hati, jiwa, kepribadian, budi pekerti, perilaku, personalitas, sifat, tabiat, temperamen, watak. ${ }^{2}$ Secara filologis, istilah karakter diasosiasikan dengan temperamen yang menekankan unsur psikologial. Seseorang juga bisa memahami karakter dari sudut pandang behavioral yang menekankan unsur somatopsikis yang dimiliki individu sejak lahir. ${ }^{3}$

Hornby dan Parnwell mengemukakan karakter artinya "kualitas mental atau moral, kekuatan moral, nama atau reputasi. ${ }^{4}$ Selanjutnya,

${ }^{1}$ Kementrian Pendidikan Nasional, 2011. Panduan Pelaksanaan Pendidikan Karakter, Pusat Kurikulum dan Perbukuan.

2 Kementerian Pendidikan Nasional, Badan Penelitian Dan Pengembangan, Pusat Kurikulum, 2010. Pengembangan Pendidikan Budaya Dan Karakter Bangsa, Pedoman Sekolah, Jakarta, h.12.

${ }^{3}$ Doni Koesoema A, 2007., Pendidikan Karakter ; Strategi Mendidik Anak di Zaman Global, Jakarta: Grasindo, h.80

${ }^{4}$ Hidayatullah, M. Furqon. 2009. Guru Sejati: Membangun Insan Berkarakter Kuat dan Cerdas. Surakarta: Yuma Pustaka.h.49. 
Muchlas Samani ber-pendapat bahwa karakter dapat dimaknai sebagai nilai dasar yang membangun pribadi seseorang, terbentuk baik karena pengaruh hereditas maupun pengaruh lingkungan, yang membedakannya dengan orang lain, serta diwujudkan dalam sikap dan perilakunya dalam kehidupan sehari-hari. $^{5}$

Sementara itu, Masnur Muslich menyatakan bahwa karakter merupakan nilai-nilai perilaku manusia yang berhubungan dengan Tuhan Yang Maha Esa, diri sendiri, sesama manusia, lingkungan, dan kebangsaan yang terwujud dalam pikiran, sikap, perasaan, perkataan, dan perbuatan berdasarkan norma-norma agama, hukum, tata krama, budaya, dan adat istiadat. $^{6}$

Berdasarkan pendapat-pendapat di atas dapat disimpulkan bahwa karakter merupakan sifat, tabiat, kepribadian, budi pekerti, atau akhlak alami sesorang yang merupakan perilaku sehari-hari dalam merespons situasi.

b. Pengertian Pendidikan Karakter

Elkind dan Sweet (dalam Kemendiknas) menyebutkan pendidikan karakter dimaknai sebagai berikut: "character education is the deliberate effort to help people understand, care about, and act upon core ethical values". Pendidikan karakter adalah suatu usaha sengaja untuk membantu orang memahami, peduli dan bertindak menurut nilai-nilai etika. ${ }^{7}$

Menurut Lickona, pendidikan karakter sebagai upaya yang sungguhsungguh untuk membantu seseorang memahami, peduli dan bertindak dengan landasan nilai-nilai etis. Pendidikan karakter menurut Lickona mengandung tiga unsur pokok, yaitu mengetahui kebaikan (knowing the good), mencintai kebaikan (desiring the good), dan melakukan kebaikan (doing the good). ${ }^{8}$

Selanjutnya Khan menyatakan bahwa, pendidikan karakter adalah proses kegiatan yang dilakukan dengan segala daya dan upaya secara sadar dan terencana untuk mengarahkan anak didik. Pendidikan karakter juga merupakan proses ke-giatan yang mengarah pada peningkatan kualitas pendidikan dan pengembangan budi harmoni yang selalu mengajarkan, membimbing, dan membina setiap manusia untuk memiliki kompetensi intelektual, karakter, dan keterampilan menarik. ${ }^{9}$

Agus Wibowo mengemukakan pendidikan karakter adalah pendidikan yang menanamkan dan mengembangkan karakter-karakter luhur kepada anak didik, sehingga mereka memiliki karakter luhur itu, menerapkan dan mempraktikkan dalam kehidupannya, entah dalam keluarga, sebagai anggota masyarakat dan warga negara. ${ }^{10}$ Selanjutnya

\footnotetext{
${ }^{5}$ Muchlas Samani \& Hariyanto, 2011., Konsep dan Model Pendidikan Karakter. Bandung: PT. Remaja Rosdakarya., h.43.

6 Masnur Muslich, 2011., Pendidikan Karakter: Menjawab Tantangan Krisis Multi dimensional. Jakarta: Bumi Aksara), h.84

7 Kementerian Pendidikan Nasional, op.cit., h.13

${ }^{8}$ Lickona, T, Schaps, E \& Lewis, C., 2003., CEP's Eleven Principles of Effective Character Education. Washington, DC: Character Education Partnership.

9 Yahya Khan, 2010. Pendidikan Karakter Berbasis Potensi Diri, Jogyakarta : Pelangi Publishing., h.34

${ }^{10}$ Agus Wibowo, 2012., Pendidikan Karakter: Strategi Membangun Karakter Bangsa Berperadab-an. Yogyakarta: Pustaka Pelajar., h. 36.
} 
Bagus Mustakim menyatakan bahwa pendidikan karakter dapat dimaknai sebagai suatu proses internalisasi sifat-sifat utama yang menjadi ciri khusus dalam suatu masyarakat ke dalam diri peserta didik sehingga dapat tumbuh dan berkembang menjadi manusia dewasa sesuai dengan nilai-nilai budaya masyarakat setempat. ${ }^{11}$

Sependapat dengan Bagus Mustakim, menurut Dony Kusuma pendidikan karakter merupakan dinamika pengembangan kemampuan yang berkesinambugan dalam diri manusia untuk mengadakan internalisasi nilainilai sehingga menghasilkan disposisi aktif, stabil dalam diri individu. ${ }^{12}$

Sintesis pendidikan karakter sebagaimana dinyatakan para ahli adalah suatu sistem penanaman nilai-nilai karakter kepada warga sekolah yang meliputi pengetahuan, kesadaran dan tindakan, baik terhadap Tuhan Yang Maha Esa, diri sendiri, sesama, lingkungan maupun bangsa dan negara.

2. Tujuan Pendidikan Karakter

Pendidikan karakter bertujuan mengembangkan nilai-nilai yang mem-bentuk karakter bangsa yaitu Pancasila, meliputi : 1) Mengembangkan potensi pe-serta didik agar menjadi manusia berhati baik, berpikiran baik, dan berprilaku baik; 2) Membangun bangsa yang berkarakter Pancasila; 3) Mengembangkan potensi warganegara agar memiliki sikap percaya diri, bangga pada bangsa dan negara-nya serta mencintai umat manusia. ${ }^{13}$

Dalam konteks yang labih luas, tujuan pendidikan karakter dapat dipilah menjadi tujuan jangka pendek dan jangka panjang. Tujuan jangka pendek dari pendidikan karakter adalah penanaman nilai dalam diri siswa dan pembaharuan tata kehidupan bersama yang lebih menghargai kebebasan individu. Tujuan jangka panjangnya adalah mendasarkan diri pada tanggapan aktif kontekstual individu, yang pada gilirannya semakin mempertajam visi hidup yang akan diraih lewat proses pembentukan diri secara terus menerus (on going formation). ${ }^{14}$

Pendidikan karakter juga bertujuan untuk meningkatkan mutu proses dan hasil pendidikan yang mengarah pada pembentukan karakter dan akhlak mulia peserta didik secara utuh, terpadu dan seimbang, sesuai dengan standar kompetensi lulusan pada setiap satuan pendidikan. Melalui pendidikan karakter peserta didik diharapkan mampu secara mandiri meningkatkan dan menggunakan pengetahuannya, mengkaji dan menginternalisasikan serta mempersonalisasikan nilai-nilai karakter dan akhlak mulia sehingga terwujud dalam perilaku seharihari. ${ }^{15}$

Dari berbagai penjelasan mengenai tujuan pelaksanaan pendidikan karakter di sekolah tersebut dapat disimpulkan pendidikan karakter di sekolah bertujuan untuk membentuk peserta didik yang tidak hanya shalih secara pribadi (normatif) tetapi juga shalih secara sosial yang terwujud dalam perilaku

\footnotetext{
${ }^{11}$ Bagus Mustakim, 2011., Pendidikan Karakter: Membangun Delapan KarakterEmas Indonesia Menuju Indonesia Bermartabat. Jogyakarta: SamudraBiru, h. 29

${ }^{12}$ Zubaedi. 2011., Desain Pendidikan Karakter: Konsep dan Aplikasinya dalam Lembaga Pendidikan. Jakarta: Kencana., h. 19

13 Kemendiknas, 2011, Panduan Pelaksanaan Pendidikan Karakter, Balitbang Kemendiknas, h.7

${ }^{14}$ Doni Koesoema A , 2010., Pendidikan Karakter Strategi Mendidik Anak Di Zaman Global, Jakarta: Grasindo,. 135

${ }^{15}$ E. Mulyasa, 2011., Manajemen Pendidikan Karakter, Jakarta: PT Bumi Aksara, h.9.
} 
sehari-hari, atau membentuk peserta didik yang mampu mengaplikasikan dzikir, fikir, dan amal shaleh dalam kehidupan sehari-harinya.

3. Nilai-nilai Pendidikan Karakter

Nilai-nilai karakter dan budaya bangsa berasal dari teori-teori pendidikan, psikologi pendidikan, nilai-nilai sosial budaya, ajaran agama, Pancasila dan UUD 1945, dan UU No. 20 Tahun 2003 tentang Sistem Pendidikan Nasional, serta pengalaman terbaik dan praktek nyata dalam kehidupan sehari-hari. ${ }^{16}$

Kemendiknas mengidentifikasi ada 18 nilai untuk pendidikan budaya dan karakter bangsa sebagai berikut ini: ${ }^{17}$. 1) Religius: sikap dan perilaku patuh dalam melaksanakan ajaran agama yang dianutnya, toleran terhadap pelaksanaan ibadah agama lain, serta hidup rukun dengan pemeluk agama lain. 2). Jujur: perilaku yang didasarkan pada upaya menjadikan dirinya sebagai orang yang selalu dapat dipercaya dalam perkataan, tindakan dan pekerjaan. 3). Toleransi: sikap dan tindakan yang menghargai perbedaan agama, suku, etnis, pendapat, sikap, dan tindakan orang lain yang berbeda dari dirinya. 4). Disiplin: tindakan yang menunjukkan perilaku tertib dan patuh pada berbagai ketentuan dan peraturan. 5). Kerja Keras: perilaku yang menunjukkan upaya sungguhsungguh dalam mengatasi berbagai hambatan belajar dan tugas, serta menyelesaikan tugas dengan sebaik-baiknya. 6). Kreatif: berpikir dan melakukan sesuatu untuk menghasilkan cara atau hasil baru dari apa yang telah dimiliki. 7). Mandiri: sikap dan perilaku yang tidak mudah tergantung pada orang lain dalam menyelesaikan tugas-tugas. 8). Demokratis: cara berpikir, bersikap, dan bertindak yang menilai sama hak dan kewajiban dirinya dan orang lain. 9). Rasa Ingin Tahu: sikap dan tindakan yang selalu berupaya untuk mengetahui lebih mendalam dan meluas dari apa yang dipelajarinya, dilihat, dan didengar. 10). Semangat Kebangsaan: cara berpikir, bertindak, dan wawasan yang menempatkan kepentingan bangsa dan negara di atas kepentingan diri dan kelompoknya. 11). Cinta Tanah Air: cara berpikir, bersikap, dan berbuat yang menunjukkan kesetiaan, kepedulian, dan penghargaan yang tinggi terhadap bahasa, lingkungan fisik, sosial, budaya, ekonomi, dan politik bangsanya. 12). Menghargai Prestasi: sikap dan tindakan yang mendorong dirinya untuk menghasilkan sesuatu yang berguna bagi masyarakat, dan mengakui, dan menghormati keberhasilan orang lain. 13) .Bersahabat dan Komunikatif: tindakan yang memperlihatkan rasa senang berbicara, bergaul, dan bekerjasama dengan orang lain. 14). Cinta Damai: sikap, perkataan, dan tindakan yang menyebabkan orang lain merasa senang dan aman atas kehadirannya. 15). Gemar Membaca: kebiasaan menyediakan waktu untuk membaca berbagai bacaan yang memberikan kebajikan baginya. 16). Peduli Lingkungan: sikap dan tindakan yang selalu berupaya mencegah kerusakan pada lingkungan alam di sekitarnya, dan mengembangkan upaya-upaya untuk memperbaiki kerusakan alam yang sudah terjadi. 17. Peduli Sosial: sikap dan tindakan yang selalu ingin memberi bantuan bagi orang lain dan masyarakat yang membutuhkan. 18). Tanggung jawab: sikap dan perilaku seseorang untuk melaksanakan tugas dan kewajibannya yang seharusnya dia lakukan, terhadap

${ }^{16}$ Zubaedi, 2011., Desain Pendidikan Karakter: Konsep dan Aplikasinya dalam Lembaga Pendidikan. Jakarta: Kencana, h.12.

${ }^{17}$ Agus Wibowo, 2012., Pendidikan Karakter: Strategi Membangun Karakter Bangsa Berperadaban. Yogyakarta: Pustaka Pelajar. 2012, h. 43-44. 
diri sendiri, masyarakat, lingkungan alam, sosial, dan budaya), negara dan Tuhan Yang Maha Esa.

Sementara itu, Ratna Megawangi berpendapat bahwa terdapat 9 pilar karakter yang berasal dari nilai-nilai luhur universal, yaitu: $\left.{ }^{18} 1\right)$. Cinta Tuhan dan segenap ciptaan-Nya, 2). Kemandirian dan tanggungjawab, 3). Kejujuran atau amanah, 4). Hormat dan santun, 5). Dermawan, suka tolong menolong dan gotong royong atau kerjasama, 6). Percaya diri dan pekerja keras, 7). Kepemimpinan dan keadilan, 8). Baik dan rendah hati.

Sintesis nilai-nilai pendidikan karakter sebagaimana dinyatakan para ahli, yaitu nilai yang berhubungan dengan Tuhan Yang Maha Esa, dengan diri sendiri, dengan sesama, dengan lingkungan dan dengan kebangsaan, yang terdiri dari nilai religius, nasionalis, mandiri, gotong royong dan integritas.

4. Pengelolaan Pendidikan Karakter di Sekolah

Pengelolaan pendidikan karakter di sekolah dapat dilaksanakan melalui proses pembelajaran baik di dalam kelas maupun di luar kelas, melalui pengelolaan sekolah dan melalui kegiatan pembinaan peserta didik.

a. Pendidikan karakter melalui proses pembelajaran

Pendidikan karakter melalui proses pembelajaran dilakukan dengan mengembangkan pembelajaran yang berpusat pada peserta didik, baik di dalam kelas maupun di luar kelas. Materi-materi substantif tentang nilainilai karakter diintegrasikan kedalam semua mata pelajaran yang diajarkan di sekolah. Pembelajaran nilai yang berlangsung secara berkelanjutan kemudian dilakukan penerapannya di dalam kehidupan sehari-hari.

Pengintegrasian dalam semua mata pelajaran, pengembangan nilai-nilai dan karakter diintegrasikan dalam setiap pokok bahasan dari setiap mata pelajaran. Nilai-nilai tersebut dicantumkan dalam Silabus dan Rencana Program Pembelajaran (RPP). Pengembangan nilai-nilai tersebut dalam Silabus ditempuh melalui cara-cara sebagai berikut: ${ }^{19}$

1) Mengkaji Standar Kompetensi (SK) dan Kompetensi Dasar (KD) untuk menentukan apakah kandungan nilai-nilai dan karakter yang secara tersirat atau tersurat dalam SK dan KD di atas sudah tercakup di dalamnya.

2) Menggunakan tabel 1 yang memperlihatkan keterkaitan antara SK/KD dengan nilai dan indikator untuk menentukan nilai yang akan dikembangkan.

3) Mencantumkankan nilai-nilai dan karakter bangsa dalam tabel 1 tersebut ke dalam silabus.

4) Mencantumkan nilai-nilai yang sudah tercantum dalam silabus ke RPP.

5) Mengembangkan proses pembelajaran peserta didik aktif yang memungkinkan peserta didik memiliki kesempatan melakukan internalisasi nilai dan menunjukan-nya dalam perilaku yang sesuai.

6) Memberikan bantuan kepada peserta didik yang mengalami kesulitan untuk internalisasi nilai mau pun untuk menunjukkannya dalam perilaku

Pendidikan karakter merupakan bagian integral dari kurikulum pada semua tingkatan. Indikator karakter terhubung dengan pelajaran di kelas adalah peserta didik dapat melihat bagaimana sebuah ciri karakter tampil dalam cerita, menjadi bagian dari eksperimen ilmiah, atau bagaimana dia

18 Jamal Ma'mur Asmani, 2011., Buku Panduan Internalisasi Pendidikan Karakter di Sekolah. Yogyakarta: Diva Press. 2011., h.51.

${ }^{19}$ Kemendiknas, 2010., op.cit. h.18 
mempengaruhi mereka. Ciri-ciri ini menjadi bagian dari pembelajaran di setiap kelas dalam setiap pelajaran.

Tabel 1

Distribusi Nilai-nilai Utama Dalam Mata Pelajaran

\begin{tabular}{|c|c|}
\hline Mata Pelajaran & Nilai-nilai utama \\
\hline Pendidikan Agama & $\begin{array}{l}\text { Religius, jujur, santun, disiplin, bertanggung } \\
\text { jawab, cinta ilmu, ingin tahu, percaya diri, } \\
\text { menghargai, keberagamaan, patuh pada aturan } \\
\text { sosial, bergaya hidup sehat, sadar akan hak dan } \\
\text { kewajiban, kerja keras dan peduli }\end{array}$ \\
\hline PKN & $\begin{array}{l}\text { jujur, menghargai keberagaman, sadar akan hak } \\
\text { dan kewajiban diri dan orang lain. }\end{array}$ \\
\hline $\begin{array}{l}\text { Bahasa } \\
\text { Indonesia }\end{array}$ & $\begin{array}{l}\text { Religius, berfikir logis, kritis, kreatif dan } \\
\text { inovatif, percaya diri, bertanggungjawab, ingin } \\
\text { tahu, santun, nasionalis. }\end{array}$ \\
\hline Matematika & $\begin{array}{l}\text { Religius, berfikir logis, kritis, jujur, kerja keras, } \\
\text { ingin tahu, mandiri, percaya diri. Tangguh, } \\
\text { demokratis. }\end{array}$ \\
\hline Bahasa Inggris & $\begin{array}{l}\text { Religius, jujur, cerdas, menghargai } \\
\text { keberagaman, santun, percaya diri, mandiri, } \\
\text { kerjasama, patuh pada aturan sosial, demokratis. }\end{array}$ \\
\hline Seni budaya & $\begin{array}{l}\text { Religius, menghargai keberagaman, nasionalis, } \\
\text { menghargai karya orang lain, ingin tahu, jujur, } \\
\text { percaya diri, demokratis, disiplin. }\end{array}$ \\
\hline Penjasorkes & $\begin{array}{l}\text { Religius, bergaya hidup sehat, kerja keras, } \\
\text { disiplin, jujur, mandiri, percaya diri, menghargai } \\
\text { karya orang lain dan prestasi orang lain. }\end{array}$ \\
\hline TIK & $\begin{array}{l}\text { Religius, berfikir logis, kreatif, kreatif dan } \\
\text { inovatif, mandiri, bertanggungajwab, dan } \\
\text { menghargai orang lain, cerdas, tangguh, } \\
\text { demokratis, nasionalis. }\end{array}$ \\
\hline Muatan lokal & $\begin{array}{l}\text { Religius, menghargai keberagaman, menghargai } \\
\text { orang lain, nasionalis, peduli, jujur, cerdas, } \\
\text { tangguh, demokratis. }\end{array}$ \\
\hline
\end{tabular}

Sumber : Kemdiknas, 2010.

Pemetaan ini menjadi kerangka konseptual yang membantu guru merencanakan sekaligus melaksanakan proses pembelajaran berbasis karakter. Langkah perencanaan selanjutnya dibuatkan silabus pembelajaran dan rencana pelaksanaan pembelajaran (RPP).

Langkah selanjutnya adalah pelaksanaan pembelajaran. Pelaksanaan pem-belajaran berbasis pendidikan karakter berorientasi pada pengembangan pengetahuan yang baik (moral knowing), perasaan yang baik atau loving good (moral feeling) dan perilaku yang baik (moral action) sehingga terbentuk perwujudan kesatuan perilaku dan sikap hidup peserta didik. $^{20}$

${ }^{20}$ Kementrian Pendidikan Nasional, 2011., Panduan Pelaksanaan Pendidikan Karakter ., Pusat Kurikulum dan Perbukuan. 
Pemaknaan pendidikan karakter bagi peserta didik dapat dilakukan dengan menerapkan metode Contextual Teaching and Learning (CTL). Menurut Jonhson dalam Sugiyanto (2007) CTL adalah sebuah proses pendidikan yang bertujuan untuk menolong para siswa melihat siswa melihat makna didalam materi akademik yang mereka pelajari dengan cara menghubungkan subyek-subyek akademik dengan konteks dalam kehidupan keseharian mereka. ${ }^{21}$ Pembelajaran dengan metode ini memotivasi peserta didik untuk menghubungkan pengetahuan yang diperoleh di kelas dan penerapannya dalam kehidupan peserta didik sebagai anggota keluarga dan warga masyarakat. Dengan model pembelajaran tersebut, intemalisasi nilai-nilai karakter dalam kegiatan pembelajaran akan membuahkan hasil belajar dan karakter yang melekat dalam diri siswa/lulusan.

Berdasarkan penjelasan tersebut guru memberi ruang pengalaman belajar pada peserta didik, terlibat aktif dalam pembelajaran dan membantunya dalam memaknai setiap pokok materi ajar.

Peran guru sangat penting dalam membuat suasana belajar di dalam kelas terbangun melalui pengintegrasian antara pengetahuan dengan sikap dan perbuatan dalam sehari-hari. Proses pembelajaran yang melibatkan langkah-langkah eksplorasi, elaborasi dan konfirmasi melalui pendekatan Contextual Teaching and Learning sebagai bentuk intervensi guru terhadap peserta didik agar menjadi siswa lulusan yang berkarakter dan berkualitas. Untuk menguatkan pengetahuan yang telah diperoleh, diberikan kesempatan pembiasaan dalam bentuk pemodelan oleh guru dan lingkungan.

b. Pendidikan karakter melalui pengelolaan sekolah

Menurut Kemdiknas, beberapa prinsip pengelolaan sekolah yang berkarakter yang hendaknya diterapkan di sekolah adalah: ${ }^{22}$

1) Kejelasan tugas dan pertanggungjawaban;

Prinsip ini menekankan adanya kejelasan tugas pokok dan fungsi setiap person yang ada, tertuang secara jelas. Dalam implementasinya, tercermin nilai-nilai amanah, terbuka, dan tanggung jawab.

2) Pembagian kerja berdasarkan the right man on the right place;

Dalam memberikan tugas kepada seseorang hendaknya berdasarkan keahlian dan kemampuan personil. Penempatan seseorang sesuai job description dari posisi yang akan ditempati. Disini tercermin nilai-nilai rasional, komitmen, dan berfikir jauh ke depan.

3) Kesatuan arah kebijakan

Prinsip ini arah kebijakan sebagai dasar pelaksanaan bagi warga sekolah jelas. Terhindar adanya kebijakan yang simpang siur atau tumpang tindih. Nilai-nilai yang diharapkan tercermin adalah bijaksana, demokratis, dan manusiawi.

4) Teratur

Hendaknya ada aturan yang disepakati bersama dan menjadi pijakan semua warga sekolah. Nilai-nilai yang muncul adalah kebersamaan, kooperatif dan dinamis.

5) Disiplin

${ }^{21}$ Sugiyanto. 2007. Modul Pendidikan dan Latihan Profesi Guru (PLPG): Model-model Pembelajaran Inovatif. Surakarta: Panitia Sertifikasi Guru Rayon 13 Surakarta.

${ }^{22}$ Kemendiknas, 2011., op.cit. h.72 
Setiap warga sekolah selalu taat asas, patuh dan konsisten terhadap aturan yang dibuat bersama. lni tercermin dalam nilai-nilai kukuh hati, menghargai waktu, dan berani berbuat benar.

6) Adil (seimbang)

Terwujudnya keseimbangan antara hak dan kewajiban, penghargaan dengan hasil karya, punishment dengan tingkat kesalahan. Nilai-nilai empati, lugas dan pemaaf tampak dalam prinsip ini.

7) Inisiatif

Setiap orang memiliki keinginan, pikiran dan gagasan, terus mengambil pra-karsa, melakukan hai baru yang positif. Di dalamnya tercermin nilai-nilai berani mengambil resiko, rendah hati, dan sabar.

8) Semangat kebersamaan

Setiap warga sekolah adalah bagian integral dan merupakan satu kesatuan. Rasa kebersamaan merupakan modal sosial yang harus dikembangkan. Nilai-nilai yang tampak adalah baik sangka, saling menghormati, dan mandiri.

9) Sinergis

Pengelolaan sekolah hendaknya dilakukan secara terpadu, saling mengisi dan melengkapi. Hal ini tercermin dalam nilai menghargai karya orang lain, tenggang rasa, dan rela berkorban.

10) Ikhlas

Pekerjaan yang telah diberlkan dilaksanakan dengan sungguh-sungguh, sebaik mungkin dengan penuh kesabaran. Nilai-nilai yang muncul diantaranya nilai pengabdian, tawakal dan syukur.

Berdasarkan prinsip-prinsip tersebut dapat disimpulkan bahwa pengelolaan sekolah menumbuhkan nilai-nilai karakter yang mewarnai setiap prinsip pengelolaan. Kegiatan pengelolaan sekolah mampu mewujudkan pengelolaan yang berkarakter. Pengelolaannya melibatkan berbagai komponen dan pemangku kepentingan sehingga tumbuh rasa memiliki dan tanggung jawab bersama.

c. Pengelolaan pendidikan karakter melalui kegiatan pembinaan

Menurut Kemdiknas (2011), kegiatan pembinaan kesiswaan menurut adalah kegiatan pendidikan yang dilakukan di luar jam mata pelajaran tatap muka. Kegiatan dilaksanakan di dalam dan/atau di luar lingkungan sekolah. Tujuannya untuk mem-perluas pengetahuan, meningkatkan keterampilan dan menginternalisasi nilai-nilai atau aturanaturan agama (Islam) serta norma sosial untuk membentuk insan yang seutuhnya. Pembinaan kesiswaan untuk membantu pengembangan peserta didik sesuai dengan kebutuhan, potensi, bakat, dan minat mereka melalui kegiatan yang secara khusus diselenggarakan oleh pendidik dan atau tenaga kependidikan yang berkemampuan dan berwenang di sekolah.

Permendiknas nomor 39 tahun 2008 tentang Pembinaan Kesiswaan menjelas-kan bahwa tujuan pembinaan kesiswaan, adalah :

1) Mengembangkan potensi siswa secara, optimal dan terpadu yang meliputi bakat, minat dan kreativitas.

2) Memantapkan kepribadian siswa untuk mewujudkan ketahanan sekolah sebagai lingkungan pendidikan sehingga terhindar dari usaha dan pengaruh negatif dan bertentangan dengan tujuan pendidikan.

3) Mengaktualisasikan potensi siswa dalam pencapaian prestasi unggulan 
sesuai bakat dan minat

4) Menyiapkan siswa agar menjadi warga masyarakat yang berakhlak mulia, demokratis, menghormati hak-hak asasi manusia dalam rangka mewujudkan masyarakat madani.

Dengan demikian maka melalui pembinaan kesiswaan, para peserta didik memperoleh kesempatan menyalurkan bakat dan minat dengan bimbingan guru sehingga dapat mengembangkan potensinya agar dapat menjadi bagian masyarakat yang baik dan berakhlak mulia.

Melalui kegiatan pembinaan kesiswaan/ekstrakurikuler dikembangkan 10 kelompok nilai karakter, (Permendiknas No. 39 Tahun 2008), yaitu:

1) Keimanan dan ketaqwaan terhadap Tuhan Yang Maha Esa.

2) Budi pekerti luhur atau akhlak mulia;

3) Kepribadian unggul, wawasan kebangsaan, dan beta negara;

4) Prestasi akademik, seni, dan/atau olahraga sesuai bakat dan minat;

5) Demokrasi, hak asasi manusia, pendidikan politik, lingkungan hidup, kepekaan dan toleransi sosial dalam konteks masyarakat plural;

6) Kreativitas, keterampilan, dan kewirausahaan;

7) Kualitas jasmani, kesehatan, dan gizi berbasis sumber gizi yang terdiversifikasi;

8) Sastra dan budaya;

9) Teknologi informasi dan komunikasi;

10) Komunikasi dalam bahasa Inggris;

Nilai-nilai yang dapat dikembangkan dalam bentuk kegiatan pembinaan kesiswaan, sebagaimana contoh berikut ini

Contoh Pembinaan Kesiswaan dan Nilai Karakter yang Ditanamkan

\begin{tabular}{|c|l|l|}
\hline No. & \multicolumn{1}{|c|}{ Bentuk Kegiatan } & \multicolumn{1}{c|}{ Contoh Nilai-nilai } \\
\hline 1 & $\begin{array}{l}\text { Pembinaan keimanan dan } \\
\text { ketaqwaan terhadap Tuhan } \\
\text { Yang Maha Esa }\end{array}$ & Religius \\
\hline 2 & Masa Orientasi Siswa & $\begin{array}{l}\text { Percaya diri, patuh pada aturan } \\
\text { sosial, disiplin, bertanggung } \\
\text { jawab, cinta ilmu, santun, sadar } \\
\text { akan hak dan kewajiban }\end{array}$ \\
\hline 3 & $\begin{array}{l}\text { Organisasi Siswa Intra } \\
\text { Sekolah (OSIS) }\end{array}$ & $\begin{array}{l}\text { Percaya, diri, kerjasama, kreatif, } \\
\text { inovasi, mandiri, bertanggung } \\
\text { jawab, disiplin, demokratis, } \\
\text { berjiwa wira usaha }\end{array}$ \\
\hline
\end{tabular}

Sumber : Kemdiknas, 2011)

\section{Metode Penelitian}

Penelitian ini bertujuan untuk mendeskripsikan tentang pengelolaan program pendidikan karakter dan hambatan-hambatan dalam pengelolaan program pendidikan karakter di SMP Al Muslim Bekasi. Desain penelitian yang digunakan adalah desain penelitian kualitatif yang mendiskripsikan pengelolaan program pendidikan karakter. 
Penelitian ini merupakan penelitian kualitatif. Moleong menekankan bahwa; "Penelitian kualitatif berakar pada latar alamiah sebagai keutuhan (entity)"23 Menurut Sugiyono, metode penelitian kualitatif adalah metode penelitian yang digunakan untuk meneliti pada kondisi obyek alamiah dimana peneliti sebagai instrumen kunci, teknik pengumpulan data dilakukan secara trianggulasi (gabungan), analisis data bersifat induktif dan lebih menekankan makna dari pada generalisasi. ${ }^{24}$

Dalam penelitian kualitatif, peneliti sebagai human instrument dan dengan teknik pengumpulan data participant observation (observasi berperan serta) dan in depth interview (wawancara mendalam), maka peneliti harus berinteraksi dengan sumber data. ${ }^{25}$

Sintesa pengertian penelitian kualitatif adalah sebuah penelitian yang dilakukan dengan cara melakukan pengamatan, wawancara dan telaah dokumen, serta melakukan pemaknaan dari obyek yang diteliti, sehingga peneliti dapat mendeskripsikan hasilnya itu yang berupa kata-kata baik tulisan maupun lisan dan gambar. Dengan demikian, peneliti mengunakan metode kualitatif untuk menghasilkan data deskriptif berupa kata-kata maupun perilaku manajemen sekolah, guru, dan peserta didik dalam pengelolaan pendidikan karakter di SMP Al Muslim Tambun.

Teknik pengumpulan data dilakukan dengan melakukan: 1) Wawancara mendalam kepada manajemen dan guru SMP Al Muslim, 2) Observasi dengan melakukan pengamatan terhadap penerapan pendidikan karakter pada siswa SMP Al Muslim kelas IX yang berjumlah 167 peserta didik, dan 3) Studi dokumentasi. Analisis data mengikuti flow model yang dikemukakan oleh Miles dan Huberman, yaitu data reduction, data display dan conclusion drawing/verification.

\section{Hasil Penelitian Dan Pembahasan}

1. Pengelolaan Program Pendidikan Karakter di SMP Al Muslim Tambun.

Pengelolaan pendidikan karakter di SMP Al Muslim Tambun pada garis besarnya dilaksanakan melalui pengelolaan sekolah, melalui kegiatan tatap muka pembelajaran dan melalui kegiatan pembinaan. ${ }^{26}$

a. Pendidikan karakter melalui pengelolaan sekolah.

Pendidikan karakter melalui pengelolaan sekolah dilaksankan melalui pengembangan profil warga SMP Al Muslim, pengembangan nilai-nilai dasar, pengembangan karakter kerja dan budaya sekolah.

1) Pengembangan profil warga SMP Al Muslim.

Warga SMP al muslim yang dimaksud adalah pendidik dan tenaga pendidikan serta peserta didik SMP Al Muslim. Profil warga SMP Al Muslim adalah manusia yang creative, confident, dan caring sebagaimana penjelasan pada tabel 2 .

Tabel 2: Profil Warga SMP Al Muslim

\begin{tabular}{|c|c|c|c|}
\hline No & Profil & Kriteria & \multicolumn{1}{|c|}{ Implementasi } \\
\hline 1 & Creative & 1. Memiliki daya cipta, & $\begin{array}{l}\text { a. Menumbuhkan rasa ingin } \\
\text { tahu }\end{array}$ \\
\hline
\end{tabular}

${ }^{23}$ Lexy J. Moleong,2007, Metodologi Penelitian Kualitatif, Edisi Revisi, Bandung: PT Remaja Rosdakarya h.8

${ }^{24}$ Sugiyono, 2005, Metode Penelitian Administrasi, Bandung: Alfabeta, h.8.

${ }^{25}$ Sugiyono, 2005., Memahami Penelitian Kualitatif, Bandung : Alfabeta, h. 6

${ }^{26}$ Hasil Wawancara dan telaah dokumen, 13 Nopember 2019 


\begin{tabular}{|c|c|c|c|}
\hline & & $\begin{array}{l}\text { 2. Memiliki kemampuan } \\
\text { memodifikasi, inisiatif } \\
\text { dan inovatif }\end{array}$ & $\begin{array}{l}\text { b. Memberikan banyak } \\
\text { gagasan dan usul dalam } \\
\text { memecahkan masalah } \\
\text { c. Memodifikasi sesuatu } \\
\text { yang sudah ada } \\
\text { d. Menghasilkan sesuatu } \\
\text { yang baru. }\end{array}$ \\
\hline 2 & Confident & $\begin{array}{l}\text { 1. Percaya diri, } \\
\text { 2. Aktif, } \\
\text { 3. Antusias, } \\
\text { 4. Berpenampilan rapi, } \\
\text { 5. Berani tampil, menge- } \\
\text { mukakan pendapat, dan } \\
\text { melakukan tindakan }\end{array}$ & $\begin{array}{l}\text { a. Percaya diri atas pen- } \\
\text { dapat yang disampaikan } \\
\text { dan keputusan yang } \\
\text { diambil } \\
\text { b. Mampu bersosialisasi ter- } \\
\text { hadap lingkungan } \\
\text { c. Memiliki keyakinan atas } \\
\text { kemampuan diri } \\
\text { sendiri } \\
\text { d. Bertanggung jawab atas } \\
\text { perbuatan yang di- } \\
\text { lakukannya } \\
\text { e. Memiliki konsep diri } \\
\text { positif } \\
\text { f. Merasa tenang disaat } \\
\text { melakukan sesuatu } \\
\text { g. Berpenampilan rapi, dan } \\
\text { bersih. } \\
\text { h. Bersemangat dalam me- } \\
\text { lakukan sesuatu yang } \\
\text { positif. }\end{array}$ \\
\hline 3 & Caring & $\begin{array}{l}\text { Peduli, empati, dan } \\
\text { berbagi }\end{array}$ & $\begin{array}{l}\text { Memiliki sikap peduli, } \\
\text { empati, dan siap berbagi } \\
\text { dengan orang lain dan } \\
\text { lingkungan. }\end{array}$ \\
\hline
\end{tabular}

2) Nilai-nilai dasar

Nilai dasar warga SMP Al Muslim adalah iman dan amal sholeh. Iman mengandung arti keyakinan kepada Allah dalam perkataan maupun perbuatan. Amal sholeh adalah melakukan aktivitas yang baik dengan hanya mengharap ridho Allah.

3) Karakter kerja

Karakter kerja pendidik dan tenaga kependidikan SMP Al Muslim mengacu pada sifat Rasulullah SAW, yakni: shiddiq, amanah, tabligh, dan fathonah;

a) Shiddiq berarti benar dalam perkataan maupun perbuatan.

b) Amanah berarti dapat dipercaya, memberikan pelayanan terbaik (pelayanan prima), dan selalu bersikap hati-hati dalam berbagai hal, baik yang berhubungan dengan dirinya, orang lain, maupun lembaga.

c) Tabligh artinya dapat menyampaikan informasi sesuai data dan fakta dengan bahasa yang baik.

d) Fathonah artinya melakukan aktivitas dengan cerdas, tekun, teliti, dan tuntas untuk mencapai tujuan. 
4) Budaya sekolah

Budaya sekolah warga SMP Al Muslim meliputi budaya disiplin, budaya 5-S, budaya bersih, budaya berbagi, budaya kerjasama, budaya literasi, dan budaya mutu.

a) Budaya disiplin meliputi disiplin dalam ibadah, belajar, dan bekerja

b) Budaya 5-S meliputi penerapan sikap 5-S (Senyum, Salam, Sapa, Sopan, dan Santun)

c) Budaya bersih meliputi bersih badan, pakaian, dan lingkungan

d) Budaya berbagi meliputi berbagi ilmu, tenaga, dan rezeki

e) Budaya kerjasama meliputi sikap saling menghormati, menghargai, berkolablorasi, dan tidak berpusat pada satu orang saja

f) Budaya literasi meliputi kegemaran membaca, menulis, dan menerapkan ilmunya dalam kehidupan sehari-hari

g) Budaya mutu meliputi upaya meningkatkan mutu pendidikan sesuai standar yang telah ditetapkan Yayasan, agar tercapai visi dan misi, serta kepuasan semua pihak.

Ukuran keberhasilan program pendidikan karakter ditentukan oleh output yaitu profil dan performance dari peserta didik maupun pendidik dan tenaga kependidikan; dan outcome dari pengelolaan program tersebut. Output merupakan hasil dari proses program yang dilaksanakan, sedangkan outcome adalah dampak positif yang ditimbulkan dari program tersebut, baik untuk kepentingan pribadi, sekolah, rumah dan masyarakat.

Hasil penelitian menunjukan profil yang mau dicapai dari proses pendidikan karakter adalah menjadi manusia yang creative, confident, dan caring. Pembentukan profil tersebut akan tercapai jika dalam prosesnya berpegang pada nilai-nilai dasar, yaitu iman dan ilmu; penumbuhan karakter kerja yang shidiq, amanah, fathonah dan tabligh dan diwujudkan dengan pembiasaan budaya sekolah, seperti budaya disiplin, budaya senyum, salam, sapa, sopan dan santun (5-S), budaya bersih, budaya berbagi, budaya kerjasama, budaya literasi, dan budaya mutu.

Iman dan ilmu merupakan pijakan dalam berbuat, dasar dalam menumbuh-kan karakter kerja dan pengembangan budaya sekolah. Iman menguatkan keyakinan tentang apa yang akan diperbuat, ilmu memberikan wawasan dan pandangan cara melakukannya. Melalui program pendidikan karakter sekolah ingin menumbuhkan dan mengembangkan karakter siswa yang memiliki basis iman dan ilmu yang mumpuni, karena ini adalah cara yang diajarkan Islam agar harkat martabat manusia meningkat sebagaimana dijelaskan dalam $\mathrm{Al}$ qur'an:

"...Allah akan meninggikan orang-orang yang beriman diantaramu dan orang-orang yang diberi ilmu pengetahuan beberapa derajat". (Q.S. Al Mujaadilah 58:11)

b. Pengelolaan pendidikan karakter melalui kegiatan belajar mengajar.

Terdapat 2 (dua) jenis kegiatan belajar mengajar yang dilakukan dalam pengembangan pendidikan karakter, yaitu kegiatan kurikuler dan kegiatan ekstra kurikuler.

1) Kegiatan kurikuler.

a) Pendidikan karakter dikembangkan secara khusus pada mata pelajaran tertentu, yaitu mata pelajaran agama dan budi pekerti, 
mata pelajaran tilawati (al Qur'an), mata pelajaran leadership dan mata pelajaran green education.

b) Pengintegrasian dalam semua mata pelajaran, pengembangan nilainilai dan karakter diintegrasikan dalam setiap pokok bahasan dari setiap mata pelajaran. Nilai-nilai tersebut dicantumkan dalam silabus dan Rencana Program Pembelajaran (RPP).

c) Melaksanakan penilaian karakter pada setiap mata pelajaran, dengan memasukan unsur sikap dalam penilaian. Terlebih di SMP Al Muslim telah menerapkan Kurikulum 2013 yang dalam penilaian hasil belajar telah mengintegrasikan penilaian karakter (sikap) yang sebesarnya $30 \%$, sedangkan selebihnya untuk penilaian aspek pengetahuan dan ketrampilan yang besarannya disesuaikan dengan karakteristik masing-masing mata pelajaran (dokumen kurikulum SMP Al Muslim).

2) Kegiatan ekstra kurikuler

Pendidikan karakter dilaksanakan dengan mengintegrasikan nilai-nilai karakter ke dalam kegiatan ekstra kurikuler, baik ekstra kurikuler yang sifatnya wajib maupun yang sifatnya pilihan. Ekstrakuler yang wajib diikuti seluruh peserta didik adalah program pramuka, sedangkan pilihan disesuai-kan dengan minat peserta didik, seperti karate, taekwondo, futsal, panahan, paskibra, dan drumband.

Nilai-nilai karakter yang dintegrasikan pada kegiatan ekstra kurikuler adalah budaya disiplin waktu, disiplin berlatih/belajar, budaya menjaga ke-bersihan, budaya 5-S meliputi penerapan sikap 5-S (Senyum, Salam, Sapa, Sopan, dan Santun), serta budaya bekerja sama yang meliputi sikap saling menghormati, menghargai, berkolablorasi, dan tidak berpusat pada satu orang saja.

Temuan di lapangan menunjukan bahwa pembinaan karakter disiplin telah berjalan dengan baik, dilihat dari waktu berkumpul yang hanya mem-butuhkan waktu kurang lebih 5 menit, dan seragam pramuka yang lengkap baik dari kakak pembina maupun peserta serta kepatuhan peserta kepada perintah atau instruksi dari kakak pembina. Demikian juga untuk ekstrakurikuler paskibra dan drumband. ${ }^{27}$

Aktivitas pembinaan $\mathrm{r}$ disiplin siswa dilaksanakan dengan sungguh-sungguh dalam kegiatan ekstrakurikuler wajib tersebut. Peserta didik antusias mengikuti semua rangkaian kegiatan dari awal sampai dengan akhir. Sehingga pembentukan karakter disiplin melalui kegiatan ekstrakurikuler bisa berjalan dengan baik sesuai dengan yang diharapkan.

c. Pengelolaan pendidikan karakter melalui kegiatan pembiasaan dan pembinaan.

Pembiasaan dan pembinaan dilakukan melalui sholat zhuhur dan ashar berjamaah yang dilanjutkan dengan kultum oleh peserta didik, masuk sekolah tepat waktu, budaya bersih pakaian, bersih lingkungan (membuang sampah pada tempatnya), budaya disiplin pakaian, budaya tertib dan disiplin makan dan minum.

Pelaksanaan program penempatan wali kelas di kelasnya sudah berlangsung selama satu tahun pelajaran. Wali kelas tidak lagi berkantor di

${ }^{27}$ Hasil observasi. 16 Nopember 2019. 
ruang guru, tapi di ruang kelas masing-masing. Para wali kelas diharapkan selain mendidik pada saat jam pelajarannya, juga mendidik pada saat tidak mengajar, karena mereka langsung berinteraksi dengan para peserta didik di kelasnya. Berdasarkan hasil pengamatan, didapatkan bahwa memang para wali kelas sudah berkantor di kelasnya masing-masing, dengan disediakan sarana penunjang seperti meja kerja, lemari arsip dan fasilitas internet. ${ }^{28}$

Manfaat lain dari program ini adalah memudahkan pemantauan terhadap interaksi, proses belajar dan hasil belajar siswa. Mengingat para wali kelas akan seharian berada di kelasnya apabila mereka tidak sedang mengajar di kelas lain. Hal ini juga dikarenakan semua wali kelas merupakan guru tetap dan guru purna waktu, yang mempunyai kewajiban untuk berada di sekolah selama sehari penuh setiap hari kerja.

Bentuk keteladanan bagi peserta didiki dikembangkan melalui kegiatan 5S. Kegiatan ini dilaksanakan setiap hari, dimana Kepala Sekolah bersama Wakil Kepala Sekolah dan guru yang bertugas melakukan penyambutan kepada seluruh peserta didik. Maksud dari kegiatan ini adalah untuk mengkondisikan agar peserta didik terbiasa berpakaian rapih dan sesuai dengan tata tertib, melaksanakan 5S, dan terbiasa datang tepat waktu. Kegiatan ini dilaksanakan mulai jam 06.30 sampai dengan 07.10.

Pembiasaan dan pembinaan peserta didik juga dilakukan dengan budaya tertib membuang sampah pada tempatnya. Di SMP Al Muslim telah dilaksanakan program pemilahan sampah, dari sampah organik dan sampah anorganik. Kemudian sampah anorganik tersebut setiap sore oleh petugas piket kelas dibawa ke bank sampah untuk ditimbang dan dicatat dalam pembukuan oleh petugas bank sampah. Nanti pada akhir periode akan dibayarkan. Sedangkan untuk sampah organiknya, dibuang ke tempat penampungan sementara di belakang sekolah, untuk kemudian pada sore harinya dibuang oleh petugas kebersihan ke tempat penampungan sampah.

Berdasarkan hasil pengamatan peneliti, hal tersebut sudah berjalan dengan tertib dan lancar, tempat sampah disiapkan sebanyak 4 (empat) buah pada tiap-tiap kelas sesuai dengan kategorinya dan siswa pun telah bisa dengan tertib membuang sampah di tempat yang semestinya, dan kepala sekolah bersama wali kelas turut mengontrol kegiatan tersebut. ${ }^{29}$

Pengelolaan pendidikan karakter melalui kegiatan pembiasaan dan pem-binaan dilaksanakan berdasarkan SOP yang telah ada dan telah disosialisasikan kepada seluruh guru dan karyawan, para siswa dan orang tua siswa. Sehingga memudahkan dalam tataran pelaksanaannya. Hal ini karena sudah jelas dan rinci setiap tindakan yang dilaksanakan dalam proses pendidikan di SMP Al Muslim Tambun, demikian juga dengan konsekuensi atas tindakan yang dilakukan.

2. Hambatan Pengelolaan Pendidikan Karakter di SMP Al Muslim Tambun,

Temuan di lapangan menunjukan masih adanya hambatan-hambatan dalam pengelolaan penddikan karakter di SMP Al Muslim Tambun baik yang diakibatkan faktor internal maupun faktor eksternal. Faktor internal internal peserta didik berupa masalah di rumah dan sikap diri; internal sekolah berupa masalah disiplin guru dan karyawan masih ada yang kurang baik. Faktor eksternal berupa sarana antar jemput siswa yang terkadang bermasalah, pembinaan dari orangtua siswa yang kurang tepat, sistem dari yayasan

\footnotetext{
${ }^{28}$ Hasil observasi, 13 Nopember 2019

${ }^{29}$ Hasil observasi, dan wawancara dengan Kepala Sekolah, 13 Nopember 2019.
} 
yang kurang mendukung khususnya masalah waktu keter-lambatan, pengaruh media sosial dan lingkungan masyarakat yang terkadang negatif.

Hasil wawancara dengan guru diperoleh informasi bahwa terdapat beberapa faktor penghambat pengelolaan pendidikan karakter di SMP Al Muslim, diantaranya jiwa kritis siswa yang agak keras sehingga sulit menerima masukan untuk perubahan, kekurangkonsistenan bapak/ibu guru dalam penerapan program kedisiplinan, masih adanya beberapa orang tua yang tidak konsisten dalam menerapkan pembiasaan disiplin ketika menerapkannya di rumah. $^{30}$

Berdasarkan hasil wawancara tersebut dan observasi menunjukan faktor penghambat pelaksanaan pembinaan disiplin siswa di SMP Al Muslim, yaitu :

a. Dari pihak siswa, masih ada sikap diri peserta didik yang kurang baik yang cenderung berbuat tidak disiplin. Walaupun sering dinasehati, tapi karena sikap diri tersebut lebih dominan, maka akan sulit meningkatkan disiplinnya dan terkadang menjadi acuan bagi peserta didik lainnya.

b. Dari pihak guru, masih ada guru yang belum konsisten dalam pelaksanaan pem-binaan karakter khususnya dalam menanamkan disiplin peserta didik. Bila masih ada guru yang kurang disiplin, akan menimbulkan kontradiktif dalam hal penegakkan disiplin kepada siswa.

c. Dari pihak yayasan, belum sinkronnya aturan masuk kerja guru dan karyawan dengan waktu masuk peserta didik. Di satu sisi aturan keterlambatan guru dan karyawan adalah jam 07.10, sedangkan pelaksanaan program pembelajaran di sekolah (sholat duha) di aula dimulai dari jam 06.45. Sehingga hal ini agak menyulitkan manajemen sekolah untuk meminta semua guru dan karyawan datang ke sekolah sebelum jam 06.45.

d. Dari pihak antar jemput peserta didik. Kendaraan antar jemput peserta didik masih bercampur, ada dari TK, SD, SMP, dan SMA. Padahal aturan masuk sekolahnya berbeda. TK mulai dari jam 07.30, di SD jam 07.00, di SMP dan di SLTA jam 06.45. Sehingga masih saja ada siswa yang terlambat karena ikut jemputan. Hal ini sudah sering dikeluhkan, tetapi belum diperoleh solusi yang tepat, karena berkaitan dengan jumlah penumpang yang apabila dipisah berdasarkan satuan pendidikannya, banyak kendaraan yang muatannya tidak memenuhi jumlah minimal untuk dihitung secara ekonomi.

e. Dari orang tua siswa, yakni ada sebagian yang belum menerapkan pola pembinaan yang diterapkan di sekolah. Di sekolah peserta didik tertib membuang sampah sesuai dengan jenis atau klasifikasinya, sementara di rumah masih ada yang belum melakukannya. Di sekolah peserta didik dididik untuk melakukan kegiatan mencuci piring sendiri, menyapu lantai dan mengepelnya, tapi di rumah sebagian tidak melaksanakannya. Sehingga masih menjadi hal yang agak sulit diterapkan secara konsisten dan berkesinambungan, mengingat perbedaan pola pendidikan antara di sekolah dengan di rumah.

\section{Kesimpulan} berikut:

Berdasarkan hasil penelitian dan pembahasan dapat disimpulkan sebagai

${ }^{30}$ Hasil wawancara dengan guru, 15 Nopember 2019 
1. Pengelolaan pendidikan karakter di SMP Al Muslim Tambun dilaksanakan melalui pengelolaan sekolah, melalui kegiatan tatap muka pembelajaran dan melalui kegiatan pembinaan:

a. Pendidikan karakter melalui pengelolaan sekolah dilaksankan dengan pengembangan profil warga SMP Al Muslim, pengembangan nilai-nilai dasar, karakter kerja dan budaya sekolah.

b. Pengelolaan pendidikan karakter melalui kegiatan belajar mengajar dilaksana-kan dengan mengembangkan kegiatan kurikuler dan kegiatan ekstra kurikuler.

c. Pengelolaan pendidikan karakter melalui kegiatan pembiasaan dan pembinaan dilakukan dengan pembiasaan shalat berjamaah, masuk sekolah tepat waktu, budaya bersih pakaian, bersih lingkungan (membuang sampah pada tempatnya), budaya disiplin pakaian, budaya tertib dan disiplin makan dan minum.

2. Hambatan pengelolaan pendidikan karakter di SMP Al Muslim Tambun di sebabkan oleh faktor internal dan faktor eksternal. Faktor internal terdiri diri peserta didik dan guru/karyawan. Sedangkan faktor eksternal terdiri dari orangtua peserta didik, antar jemput peserta didik dan Yayasan

\section{Daftar Pustaka}

Agus Wibowo, 2012., Pendidikan Karakter: Strategi Membangun Karakter Bangsa Berperadaban. Yogyakarta: Pustaka Pelajar.

Bagus Mustakim,2011., Pendidikan Karakter: Membangun Delapan Karakter Emas Indonesia Menuju Indonesia Bermartabat. Jogyakarta: Samudra Biru.

Chelsea E. Graff, 2012. The Effectiveness of Character Education Programsin Middle and High Schools", The College at Brockport, State University of New York.

Doni Koesoema A, 2010., Pendidikan Karakter Strategi Mendidik Anak Di Zaman Global, Jakarta: Grasindo.

E. Mulyasa, 2011., Manajemen Pendidikan Karakter, Jakarta: PT Bumi Aksara.

Hidayatullah, M. Furqon. 2009. Guru Sejati: Membangun Insan Berkarakter Kuat dan Cerdas. Surakarta: Yuma Pustaka.

Jamal Ma'mur Asmani, 2011., Buku Panduan Internalisasi Pendidikan Karakter di Sekolah. Yogyakarta: Diva Press.

Joyce Ann King, 2008. An Evaluation of a Character Education Program at an Elementary School", Nova Southeastern University.

Lexy J. Moleong,2007, Metodologi Penelitian Kualitatif, Edisi Revisi, Bandung: PT Remaja Rosdakarya.

Lickona, T, Schaps, E \& Lewis, C., 2003., CEP's Eleven Principles of Effective Character Education. Washington, DC: Character Education Partnership.

Masnur Muslich, 2011., Pendidikan Karakter: Menjawab Tantangan Krisis Multi dimensional. Jakarta: Bumi Aksara.

Muchlas Samani \& Hariyanto, 2011., Konsep dan Model Pendidikan Karakter. Bandung: PT. Remaja Rosdakarya.

Sugiyono, 2005., Memahami Penelitian Kualitatif, Bandung : Alfabeta.

Yahya Khan, 2010. Pendidikan Karakter Berbasis Potensi Diri, Jogyakarta : Pelangi Publishing. 
| Isep Djuanda

Zubaedi. 2011., Desain Pendidikan Karakter: Konsep dan Aplikasinya dalam Lembaga Pendidikan. Jakarta: Kencana. 
Deskripsi Pengelolaan Pendidikan Karakter... |

180 | Alim | Journal of Islamic Educatioan 